\title{
FIATAL VERSENYSPORTOLÓK ÉTKEZÉSI SZOKÁSAINAK VIZSGÁLATA
}

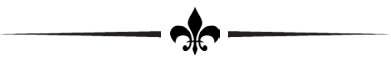

\section{EXAMINATION OF THE YOUNG ATHLETES’ EATING HABITS}

\author{
ia \\ FOLTIN, BIANKA \\ KISS, VIRÁG ÁGNES \\ \&o. \\ Debreceni Egyetem, Gazdaságtudományi Kar, Marketing és Kereskedelem Intézet \\ (University of Debrecen, Faculty of Economics and Business, Institute of Marketing and Commerce) \\ H-4032 Debrecen, Böszörményi út 138. \\ e-mail: biankafoltin@gmail.com
}

\begin{abstract}
8 Nowadays, movement and maintaining health are becoming more and more prominent in both public life and the scientific world. In connection with this, we can meet many scientific developments and new recommendations. In the present research, we examined young athletes, primarily in terms of their eating habits, as the compilation of a proper diet contributes greatly to the ability of athletes to achieve the best possible results. The aim of the secondary search was to get acquainted with the young athletes' health-consciousness behavior and eating habits. The primary search consisted of an online-, and paper based questionnaire as well. As far as data analysis is concerned, we only considered data given by the targeted segment of the respondents, which falls between the age of 15 and 35. For statistical analysis we used descriptive statistics and crosstabs procedure. The results revealed that the majority of the athletes eat 3-5 times a day both in preparation and competiton period. Furthermore, the overwhelming majority of athletes find conscious eating important, however, they did not find either the consumption of different health protecive or disease preventive food important. They also do not follow the latest trends in connection with sportfood.
\end{abstract}

KuLCSSZAVAK: egészségtudatosság, egészséges táplálkozás, fiatalok, versenysport, versenysportolók

JEL-KóDoK (JEL CODES): M31, H12, Z2

DOI: https://doi.org/10.20494/TM/7/1/6

\section{BEVEZETÉS - INTRODUCTION}

A vizsgálatunkat azzal az előzetes feltevéssel indítottuk el, hogy tekintettel az egyre nagyobb teret nyerő egészségtudatossági trendekre (új táplálkozási irányzatok, speciális, új diéták és innovatív funkcionális élelmiszerek) a fiatalok, és fóleg a sportoló fiatalok esetében egyre nagyobb érdeklődésre tart számot ezek követése.

BAGDY (2010) definíciója alapján az egészségtudatos egyén vállalja a felelősséget önma-
KEYwORDs: health-consciousness, healthy eating, youth, competitive sport, competitive sportsmen

gáért, saját maga egészségéért, és gondoskodik jó közérzetéről és testi-lelki egyensúlyáról. SZAKÁLY (2009) szerint az elmúlt években a megváltozott életstílus következtében változnak a fogyasztók értékei is és egyre inkább előtérbe kerül egészségük megőrzése, ami elsősorban a táplálkozásban nyilvánul meg. Tehát a fogyasztók egyre nagyobb jelentőséget tulajdonítanak a megfelelő összetevőjú élelmiszereknek.

Vizsgálatunkban ezt a trendet igyekeztünk 
feltérképezni a fiatal versenysportolók körében, hogy mennyire hatnak rájuk az új irányzatok, ajánlások, mennyire érzik magukhoz közelinek ezeket. Jelen esetben elsősorban az étkezési szokásaikat illetően vizsgáltuk ezt a kérdést.

Mivel az orvostudományban is kiemelt jelentőséggel bír az egészség minél hosszabb távon történő megóvása, így egyre több kutatás és innováció jelenik meg ennek elősegítésére. A táplálkozáshoz kapcsolódóan az élelmiszeripar és az orvostudomány már szoros együttmúködésben fejlődik, ezáltal egyre több fogyasztó igényeit elégítve ki. Az elmúlt években többszörösére nőtt a sportolók számára fejlesztett élelmiszerek kínálata, sőt már az egyes sportágak mentén is megtalálhatóak a speciális táplálkozási útmutatások és étrendkiegészítők.

A versenysportolók, de fóleg a fiatalabb versenysportolók esetében kiemelt jelentőségü a rendszeres étkezés és a megfelelő tápanyagok bevitele, hiszen jóval nagyobb energiákat emészt fel szervezetük nap mint nap. Ez azt is jelenti, hogy azoknál az egyéneknél, akik napi szinten minimum másfél órát intenzíven edzenek, napi 3-6 ezer kcal-re nő az energiaigényük a kiegyensúlyozott életvitelhez. Az ezenbelüli differenciák jellemzően a nem, a kor és a választott/űzött sportág mentén alakulnak ki (FIGLER, 2005). Fejlődésük, teljesítményük szinten tartását és növelését nagyban meghatározza az elfogyasztott ételek minősége és menynyisége.

\section{SZAKIRODALMI ÁTTEKINTÉS -} THEORETICAL BACKGROUND

Szekunder kutatásunk során hazai és külföldi szakirodalmakat kerestünk fel és elemeztünk: szakcikkeket, disszertációkat, kutatásokat, adatbázisokat és statisztikai eredményeket. Meghatároztuk az egészségmagatartás és egészségtudatosság fogalmát, valamint a sportolók táplálkozásával kapcsolatos szakcikkekből tájékozódtunk.

\subsection{Egészségmagatartás és egészség- tudatosság - Health Behaviour and Health Consciousness}

Az egészségmagatartás értelmezése kapcsán számos forrással találkozhatunk, melyek szerint idetartozik minden olyan cselekvés, ami az egyén megítélése szerint segít az egészség megőrzésben, betegség megelőzésben, illetve azonosításban még annak kialakulása előtt (KASL - COBB, 1996; URBÁN, 2001; DUDÁS, 2015), míg HARRIS és GUTEN (1979) ezt kiegészíti azzal, hogy ezek függetlenek attól, hogy milyen az egészségi állapota, illetve, hogy az adott viselkedésnek kimutathatóan hatékony a hatása vagy sem (SZAKÁLY, 2008). Harris és Guten egészségmagatartás modelljének legfontosabb elemei: fizikai aktivitás, tudatos táplálkozás, személyi higiéné, rendszeres önellenőrzés, szerrel való visszaélések elkerülése, kiegyensúlyozott lelki élet, pihenés higiéniája, szűrővizsgálatok (SZAKÁLY, 2008; KISS et al., 2016).

DUDÁS (2015) szerint az egyénnek minden tevékenysége hatással van egészségi állapotára, valamilyen (pozitív/negatív) módon. Az egészségmagatartás elemei a pozitív változásokat segítik elő, illetve a negatívokat előzik meg. URBÁN (2001) az egészségmagatartás kapcsán szelektálta és csoportosította az erre vonatkozó magatartásformákat (URBÁN, 2001; FOLTIN, 2019):

- Táplálkozással kapcsolatos magatartás, mint pl. az alacsony kalória- és zsírtartalmú diéta, vagy a testsúly szabályozása.

- Szexualitással kapcsolatos magatartás, mint pl. a biztonságos szexuális aktusok.

- Fizikai aktivitással és sporttal kapcsolatos magatartás, mint pl. a rendszeres testmozgás, vagy a megeróltető sportok kerülése.

- Addikcióval kapcsolatos viselkedések, azaz a káros szenvedélyekhez vezető tevékenységek kerülése, vagy a leszokás.

- Higiéniával kapcsolatos viselkedések, mint pl. a megfelelő tisztálkodás.

- Fizikai megjelenéssel kapcsolatos viselkedések, tehát az olyan viselkedés kerülése, amely negatívan hat megjelenésünkre, mint pl. túlzott napozás kerülése. 
- Helyváltoztatással/utazással kapcsolatos magatartások, mint pl. a sebességhatárok betartása.

- Betegséggel és gyógyulással kapcsolatos viselkedések, mint pl. rendszeres szürővizsgálatokon való részvétel, önellenőrzés gyakorlása, betegség esetén orvos felkeresése.

\subsection{Sportolók táplálkozása - Athletes' Diet}

A sportolók táplálkozását illetően a sporttáplálkozás és a sportolói táplálkozási piramis témakörét ismertetjük részletesen.

\subsubsection{Sporttáplálkozás - Sports Nutrition}

Ahogyan azt a bevezetésben megfogalmaztuk, a táplálkozás tudományos vetületének fontos területévé vált az elmúlt években a sporttáplálkozás. Ez nem azt jelenti, hogy akár évezredek előtt ne lettek volna tisztában a tápanyagbevitel milyenségének fontosságával, hiszen a görög sportolók körében a „tréningdiéta” elterjedt és ismert volt már az ókori játékok során is. Ezen diétában a magas fehérjebevitel jelentôségét már felismerték, és hús-alapú étrendet folytattak a sportolók. Ez a 20. században vált kiterjedtebbé, mikor a húson túl felismerték a további fehérje formák jótékony hatását, és a technológiai lehetőségeket felhasználva már a személyre szabottság és a pontosabb mérések (nem, kor, metabolizmus) segítik a sportolókat a legmegfelelőbb tápanyag-bevitel megvalósításában (számítógépes programok, szakemberek, mérések). Fontosnak tartják továbbá a sportág- és az edzésintenzitás-specifikus szegmentációt. Ez azért is fontos, mert már tudományosan bizonyított az anyagcsere folyamatok kapcsán a sport területén aktív és inaktív egyének (aktívak: $+5 \%$ ), illetve a nemek (férfiak $+5-10 \%$ ) és a korcsoportok (10 évente $-2-3 \%$ ) közötti jelentős különbség. (FIGLER, 2015).

A sporttáplálkozáson belül fontos megkülönböztetni a terhelési ciklusokat, mint felkészülési, átmeneti vagy versenyidőszak (NYAKAS, 2009). Ezen periódusok között jelentős tápanyag-beviteli különbségek figyelhetőek meg. A másik differenciáló aspektus a szaba- didő-, az egészség- és a profisport, amik szintén más és más energiaszintet kívánnak meg (TIHANYI et al., 2015).

A sportágak mentén történő csoportosítást SILYE (2017) és FOLTIN (2019) az alábbiak deklarálta, aszerint hogy milyen erőt igényelnek:

- állóképességet és erőt,

- állóképességet és gyors reakciót,

- gyors reakciót és szubmaximális és maximális erőt,

- gyors erőkifejtést,

- gyors reakciót és legfeljebb szubmaximális erót.

Ezen csoportosításnak hála a szakemberek számára az átlagos energiaszükségletet napi és óránkénti vonatkozásban is személyre vagy sportágra szabottan tudják meghatározni. Kiemelten fontos továbbá ezek ismerete, mivel sok esetben a sportolók nem tudnak szervezetükbe megfelelő minőségű és mennyiségű tápanyagot bevinni az edzések okán gyakran bekövetkezó étvágyhiány vagy „teli hassal történő” edzés elkerülése miatt, ami viszont egészségtelen hatáshoz vagy komoly problémákhoz vezethet, mint súly- vagy izomveszteséghez, ami a teljesítményre is negatív hatással van (MIKULÁN, 2019). A legtöbb esetben maga a pontosan, előre meghatározott célok mentén történő étrend kialakítás (rost-, vitamin-, ásványi anyagbevitel) sokat segít a kiváló teljesítmény elérésében, azonban ha ezek nincsenek előzetesen meghatározva vagy az egyén ezeket figyelmen kívül hagyja fordított hatást (alacsony teljesítményt) érhet el az intenzív edzés mellett is. A sportemberek esetében a táplálkozás fő célja, hogy támogassa a magas intenzitású edzéseket és növelje teljesítőképességüket (MAUGHAN, 2002; FOLTIN, 2019). További szempontok még az energiaigény pontos felismeréséhez a megfelelő testzsír százalék és izomösszetétel fenntartás okán, a szénhidrát bevitel (izomzat glikogén igénye okán), a tápanyagtípus formája, beviteli ideje, a fehérjebevitel (izomregeráció), illetve a folyadékpótlás. Ezek figyelembevételét javasolják a szakemberek, továbbá a mértékletességet és a diéták betartását, mivel ezek hiányában hiányosságok alakulhatnak ki, mert a tápanyagok nem vagy nem felelően szívódnak fel (MAUGHAN, 2002).

Hogy pontosan mit és milyen arányban 
érdemes fogyasztani a szabadidő vagy akár a versenysportot űzőknek, a BOROS (2008) féle táplálkozási piramis jól mutatja.

$\mathrm{Az}$ 1. ábrán látható a folyadékpótlás fontossága, ami lehet ásványvíz, izotóniás ital és egyéb folyadék. A következő szinten a gabonafélék helyezkednek el. Nagyon fontos a gyorsan felszívódó, energiát biztosító ételek, mint a rizs és burgonya fogyasztása. A zöldségek, gyümölcsök a vitaminok mellett rost, ásványi anyag, összetett szénhidrát források is. A tejtermékek segítenek az immunvédelemben, edzés után tanácsos fogyasztani őket. A hal fogyasztását magas fehérje és az omega-3 zsírtartalma miatt ajánlják a sportolók diétájába. A zsírok, olajok, édességek állnak a piramis csúcsán, mivel fogyasztásuk megterheli az anyagcserét és így csökkenti a teljesítőképességet (BOROS, 2008).
Egyes élelmiszerek fogyasztása különösen fontos az élsportban. Ezek a következők: sovány vörös-, és szárnyashús; lazac; tojás; alacsony zsírtartalmú, natúr joghurt; protein szupplementáció (tejsavó, kazein); paraj; paradicsom; keresztesvirágzatú zöldségek (brokkoli, káposzta, karfiol); bogyós gyümölcsök (málna, szamóca, áfonya); narancs; babfélék (fehérbab, lóbab, vörösbab stb.); teljes kiőrlésü zab; olajos magvak (kesudió, dió stb.); avokádó; olívaolaj; halolaj; lenmag; zöldtea; banán; görögdinnye. A szénhidrátbevitel a napi tápanyagszükséglet és a regeneráció gyorsítása miatt fontos, míg fehérje fogyasztása edzés után ajánlott a hatékony izomerőfejlesztés és a kedvező testösszetétel céljából. Általánosságban pedig elmondható, hogy a zsírbevitelt nem ajánlott a teljes energiabevitel 20\%-a alá csökkenteni (BOROS, 2008: 93).

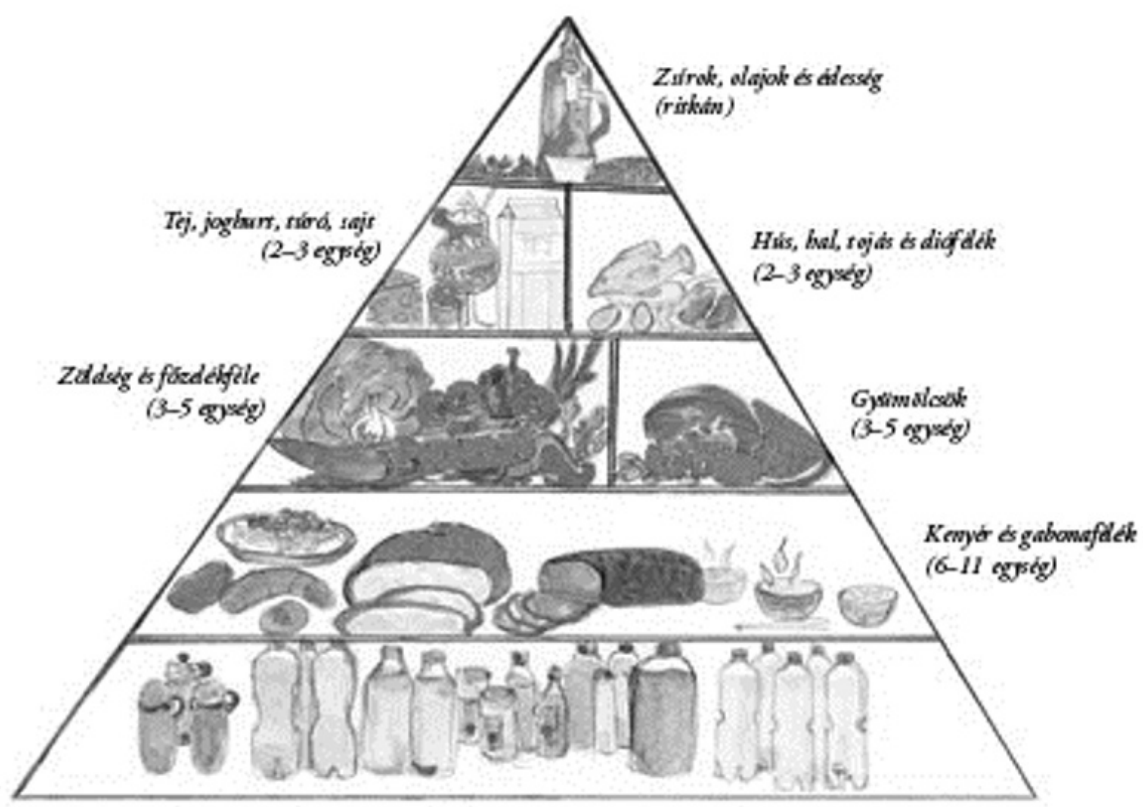

Fdyadde (destiveres, izosinids ìal mb.)

\section{1. ÁBRA}

Forrás (Source): BOROS (2008:92) (Nutritional Pyramid for Athletes)

Notes: from bottom to top: beverages (mineral water, isotonic drinks, etc.; bread, cereals - 6-11 units; fruits and vegetables 3-5 units; dairies and meat, fish, eggs and nuts - 2-3 units; fat, oil and sweets - rarely) 


\section{ANYag ÉS MódSZERTAN - MATERIAL AND METHOD}

Kutatásunk célja, ahogy azt korábban is ismertettük a fiatal versenysportolók egészségtudatos fogyasztói magatartásának feltérképezése volt, ezen belül is az egészségtudatos étkezéssel kapcsolatos általános attitúdjeik felmérése és az étkezés gyakoriságának vizsgálata.

A kérdőív kitöltése 2018-ban elsősorban online formában történt, de papír alapon is volt kitöltés a célcsoport tagjaival. A vizsgálatba célcsoport-specifikusan 203 főt vontunk be, azonban a kor (15-35) és egyéb szegmentációs ismérvek okán végül 190 fó válaszait dolgoztuk fel. A minta nem reprezentatív, azonban ha-

\section{TÁBLÁZAT}

A válaszadók megoszlása a háttérváltozók szerint, $\mathrm{N}=190$ (Distribution of the Respondents Based on the Background Variables)

\begin{tabular}{|c|c|c|c|}
\hline & Megnevezés (Criterion) & $\begin{array}{c}\text { Fö } \\
\text { (Capita) }\end{array}$ & $\%$ \\
\hline \multirow{2}{*}{ Neme (Gender) } & Férfi (Man) & 93 & 48,9 \\
\hline & Nő (Woman) & 97 & 51,1 \\
\hline \multirow{3}{*}{ Korcsoport (Age group) } & $15-19$ & 92 & 48,4 \\
\hline & $20-24$ & 88 & 46,3 \\
\hline & 25-35 & 10 & 5,3 \\
\hline \multirow{4}{*}{$\begin{array}{l}\text { Családi állapot (Marital } \\
\text { status) }\end{array}$} & Nőtlen/hajadon (Single) & 150 & 78,9 \\
\hline & Házas (Married) & 3 & 1,6 \\
\hline & Élettársi kapcsolatban él (In relationship) & 36 & 18,9 \\
\hline & Elvált (Divorced) & 1 & 0,5 \\
\hline \multirow{4}{*}{$\begin{array}{l}\text { Háztartás jövedelme éves } \\
\text { szinten (Annual income of } \\
\text { the household) }\end{array}$} & $\begin{array}{l}\text { Jövedelmemból mindenre futja, sôt félre is tudok tenni. (Can } \\
\text { live on it very well and can also save.) }\end{array}$ & 85 & 45,0 \\
\hline & $\begin{array}{l}\text { Nincsenek anyagi gondjaim, de félre már nem tudok tenni. (Can } \\
\text { live on it, but can save a little.) }\end{array}$ & 85 & 45,0 \\
\hline & $\begin{array}{l}\text { Jövedelmem éppen csak fedezi költségeimet. (Just enough to } \\
\text { live on, but cannot save.) }\end{array}$ & 14 & 7,4 \\
\hline & $\begin{array}{l}\text { Jövedelmem még a költségeimet sem fedezi. (Income does not } \\
\text { cover our costs.) }\end{array}$ & 5 & 2,6 \\
\hline \multirow{4}{*}{$\begin{array}{l}\text { Lakóhelye típusa (Type of } \\
\text { residence) }\end{array}$} & Főváros (Capital city) & 14 & 7,4 \\
\hline & Megyei jogú város (County town) & 87 & 45,8 \\
\hline & Város (City) & 80 & 42,1 \\
\hline & Község (Township) & 9 & 4,7 \\
\hline \multirow{3}{*}{$\begin{array}{l}\text { Legmagasabb iskolai } \\
\text { végzettsége (Highest school } \\
\text { qualification) }\end{array}$} & Maximum 8 általános (Maximum 8 years at primary school) & 70 & 36,8 \\
\hline & Érettségi (GCSE) & 97 & 51,1 \\
\hline & Felsőfokú végzettség (Higher education graduate) & 23 & 12,1 \\
\hline
\end{tabular}

Forrás (Source): Saját szerkesztés a kérdőíves megkérdezés alapján, 2019 (Author’s own compilation according to questionnaire survey, 2019) 
fele-fele arányban vettek részt a kutatásban a férfiak és a nők. A kor esetében fontos kiemelni, hogy a 25 éves kor feletti korosztály alulreprezentált, így eredményeink is elsősorban a 15-25 éves korosztály véleményét tükrözik. Korukból is fakadóan felülreprezentáltak az egyedülállók, illetve a maximum érettségivel rendelkezők. A jövedelmi helyzet kapcsán pedig 90\%-uk nem küzd anyagi nehézségekkel, sőt kifejezetten jó anyagi körülmények között él, azaz az egészségvédő termékek piacának kevéssé árérzékeny csoportjának tagjai. Mivel vizsgálatunk elsősorban a hajdú-bihari, Debrecenben sportolókra irányult, így nem meglepő, hogy a válaszadók 45,8\%-a él megyei jogú városban, míg 42,1\% városban.

Továbbá fontos bemutatni az edzések gyakoriságának megoszlását a megkérdezettek esetében, mivel később háttérváltozóként használjuk őket az elemzés során (2. táblázat).

Edzések gyakoriságának megoszlása az edzési ciklusok szerint, \% (Frequency of Trainings Based on the Different Periods, \%)

\begin{tabular}{|c|c|c|}
\hline \multirow{2}{*}{$\begin{array}{c}\text { Edzések gyakorisága hetente (Number of } \\
\text { trainings per week) }\end{array}$} & \multicolumn{2}{|c|}{ Időszaktípus (Type of period) } \\
\hline & $\begin{array}{l}\text { Felkészülési idószakban } \\
\text { (During preparation period) }\end{array}$ & $\begin{array}{l}\text { Versenyidószakban } \\
\text { (During competition) }\end{array}$ \\
\hline 1-3 alkalom (1-3 times) & 25,00 & 23,94 \\
\hline 4-6 alkalom (4-6 times) & 46,81 & 65,43 \\
\hline 7-10 alkalom (7-10 times) & 24,47 & 3,04 \\
\hline több mint 10 (more than 10 times) & 3,72 & 1,60 \\
\hline
\end{tabular}

Forrás (Source): Saját szerkesztés a kérdőíves megkérdezés alapján, 2019 (Author's own compilation according to questionnaire survey, 2019)

\section{Eredmények - Results}

A következőkben a sportolók napi étkezésének gyakoriságának és az élelmiszerválasztással kapcsolatos attitűdük vizsgálata során feltárt fontosabb eredmények kerülnek bemutatásra.

\subsection{A sportolók napi étkezésének gyakorisága - Frequency of Meals of Athletes' Per Day}

A 2. ábra alapján vizsgált fiatalok körében a legjellemzőbb az ajánlott (BOROS, 2008) 3-5 alkalommal történő étkezés (nassolás nélkül) (+64\%) mindkét vizsgált időszakban. Ugyanakkor megjelent a 3-nál kevesebbszer étkezők tábora is, bár csak 12-13\%-ban, ami fóleg fiatalkorban veszélyes sportolás mellett. A két periódust külön vizsgálva láthatjuk, hogy a versenyidőszakban nagyobb arányban csökken az 5-nél többszöri étkezések aránya, mint amenynyire a kevesebb mint 3 étkezések száma nő.

Kereszttáblás elemzéssel vizsgálva a két időszakot a tizenöten növelték az étkezés gyakoriságát, 35 fó pedig csökkentette azt, azonban a legtöbben nem változtatnak a verse- nyidőszakban sem ezen ( $\mathrm{p}<0,001)$.

További kereszttáblás elemzéseink során kiderült, hogy a nemek között eltérés van e kérdésben, és inkább a lányok azok, akik hajlamosak kihagyni étkezéseket ( $\mathrm{p}<0,05)$, míg a fiúk főleg a versenyidőszakban növelik azok számát ( $\mathrm{p}<0,05)$. Továbbá, hogy a lakóhelyük szerint vizsgálva a községben vagy kisvárosban élők, akik a háromnál kevesebb evést érzik magukra jellemzőnek, míg a megyeszékhelyről érkezők az ajánlások szerint táplálkoznak $(\mathrm{p}<0,05)$. Sajnálatos módon az anyagi helyzet is determinálja, hogy a fiatal versenysportolók hányszor esznek egy nap, hiszen bár kevesen voltak a mintában a rossz anyagi körülmények között élők, mégis náluk szignifikánsan jellemzőbb volt a ritka, kevesebb mint 3 étkezés $(\mathrm{p}<0,01)$.

Továbbá szignifikáns eltérést találtunk az edzések száma (felkészülési/versenyidőszak külön) és az étkezés között. A felkészülési időszakban jellemző, hogy akik gyakrabban edzenek, többet esznek. A 3-nál kevesebbszer étkezők csoportjában jellemzően az alacsony edzés szám jelenik meg $(\mathrm{p}<0,01)$. A versenyidőszakban mérsékeltebben, de ugyanezt a trendet láthatjuk $(\mathrm{p}<0,05)$. 


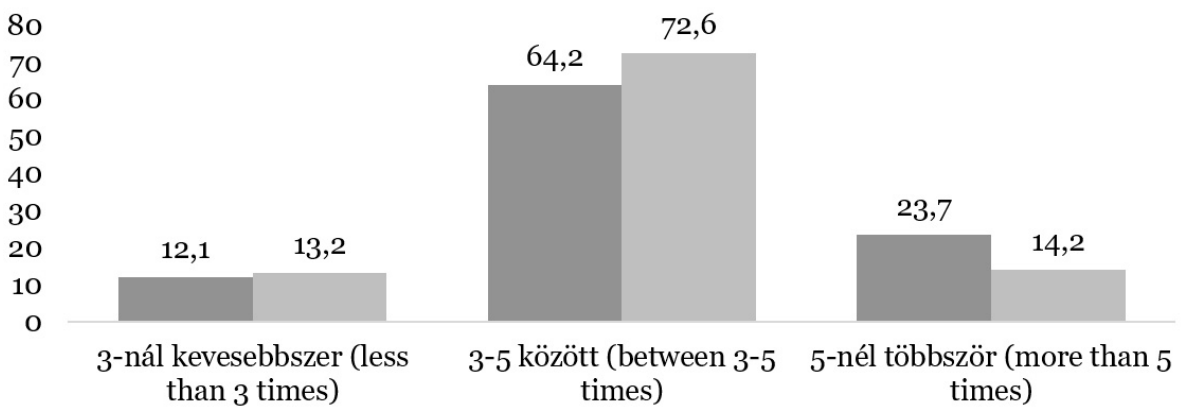

• Felkészülési időszak (Preparation period) $₫$ Versenyidőszak (Competition period)

2. ÁBRA

Versenysportolók napi étkezéseinek száma a felkészülési - és a versenyidőszakban (\%)

(The Number of Athletes' Meals Per Day During Preparation and Competition, \%)

Forrás (Source): Saját szerkesztés a kérdőíves megkérdezés alapján, 2019 (Author's own compilation according to questionnaire survey, 2019)

\section{2. Étkezéssel és az élelmiszerválasz- tással kapcsolatos attitüdök vizsgá- lata - The Examination of Attitudes in Terms of Diet}

Ahogyan azt már korábban említettük, a kiegyensúlyozott táplálkozás kiemelten fontos a sportolók esetében, és a növésben lévő szervezetnél ez még hangsúlyosabb. Ebben még környezetük erős hatással lehet rájuk, viszont az önálló döntéshozatal és az ehhez szükséges ismeretek felértékelődnek esetükben.
Az egészségtudatos táplálkozással kapcsolatos attitűdjeiket Likert-skálás kérdésekkel vizsgáltuk, majd ezeket leíró statisztikai mutatók alapján elemeztük.

Először a fizikai aktivitás és a tudatos táplálkozás kapcsán kérdeztük meg őket, menynyire tartják ezeket fontosnak. A 3. táblázatból kiderül, hogy sportolóként a fizikai aktivitást magasabb prioritásúnak ítélték, mint a táplálkozást, már valós eltérést csak az átlag esetében láthatunk.

A tudatos táplálkozás és a fizikai aktivitás fontosságának megítélése (The Importance of Health-Conscious Diet and Physical Activity)

\begin{tabular}{lccccc}
\hline $\begin{array}{c}\text { Egészségmagatartás elemek (The } \\
\text { elements of health behavior) }\end{array}$ & $\begin{array}{c}\text { Átlag } \\
\text { (Mean) }\end{array}$ & $\begin{array}{c}\text { Medián } \\
\text { (Median) }\end{array}$ & $\begin{array}{c}\text { Módusz } \\
\text { (Mode) }\end{array}$ & $\begin{array}{c}\text { Szórás } \\
\text { (Variance) }\end{array}$ & $\begin{array}{c}\text { Ferdeség } \\
\text { (Skewness) }\end{array}$ \\
\hline Tudatos táplálkozás (Helath-conscious diet) & 4,42 & 5 & 5 & 0,903 & $-2,054$ \\
\hline Fizikai aktivitás (Physical activity) & 4,63 & 5 & 5 & 0,805 & $-2,786$ \\
\hline
\end{tabular}

Forrás (Source): Saját szerkesztés a kérdőíves megkérdezés alapján, 2019 (Author’s own compilation according to questionnaire survey, 2019)

Megjegyzés (Notes): 1 - egyáltalán nem fontos, 5 - nagyon fontos (1 - not important, 5 - really important)

A következőkben pedig részletesebb állítások mentén kellett saját hozzáállásukról viszszajelzést adni (4. táblázat). Az eredmények esetében a legmeglepőbb, hogy bár elismerik a korábbi eredmények alapján a táplálkozás kiemelt szerepét életükben periódustól függetlenül jónak vagy közepesnek értékelik saját hozzáállásukat a kérdéshez (maximum átlagérték = 3,72). A módusz maximuma az ösz- szes kérdést tekintve 4. Ettől függetlenül döntô többségük inkább odafigyel a különböző periódusokban a kiegyensúlyozott táplálkozásra, és kedveli a funkcionális élelmiszereket. Negatívnak mondható azonban, hogy az ajánlásokat nem ismerik, tartják be. Az újdonságokra sem nyitottak, és bio hívószó preferálása, továbbá a sport-táplálkozás-kiegészítők fogyasztása pedig inkább nem jellemző rájuk. 
Étkezéssel kapcsolatos attitúdök vizsgálata a fiatal sportolók esetében (The Examination of Young Athletes'Attutide Touards Diet)

\begin{tabular}{|c|c|c|c|c|c|}
\hline Állítások (Statements) & $\begin{array}{l}\text { Átlag } \\
\text { (Mean) }\end{array}$ & $\begin{array}{l}\text { Medián } \\
\text { (Median) }\end{array}$ & $\begin{array}{l}\text { Módusz } \\
\text { (Mode) }\end{array}$ & $\begin{array}{c}\text { Szórás } \\
\text { (Variance) }\end{array}$ & $\begin{array}{c}\text { Ferdeség } \\
\text { (Skewness) }\end{array}$ \\
\hline $\begin{array}{l}\text { Felkészülési időszakban is odafigyelek az } \\
\text { egészséges, kiegyensúlyozott táplálkozásra. ( } \\
\text { pay attention to follow a well-balanced diet } \\
\text { during preparation period.) }\end{array}$ & 3,72 & 4 & 4 & 1,045 & $-0,715$ \\
\hline $\begin{array}{l}\text { Versenyszezonban kifejezetten odafigyelek az } \\
\text { egészséges, kiegyensúlyozott táplálkozásra. ( } \\
\text { pay attention to follow a well-balanced diet } \\
\text { during competition period.) }\end{array}$ & 3,71 & 4 & 4 & 1,058 & $-0,714$ \\
\hline $\begin{array}{l}\text { Előnyben részesítem azokat az élelmiszereket, } \\
\text { amelyek egészségvédő vagy betegség-meg- } \\
\text { előző jellemzőkkel rendelkeznek. (I prefer } \\
\text { products with features supporting one’s } \\
\text { health or preventing diseases.) }\end{array}$ & $3,5^{2}$ & 4 & 4 & 1,121 & $-0,543$ \\
\hline $\begin{array}{l}\text { Az étrend összeállításakor követem az orvos- } \\
\text { tudomány mai ismeretei alapján megfogal- } \\
\text { mazott táplálkozási ajánlásokat. (I follow the } \\
\text { doctors' recommendations when setting up } \\
\text { my diet.) }\end{array}$ & 3,12 & 3 & 3 & 1,099 & $-0,291$ \\
\hline $\begin{array}{l}\text { Szívesen próbálok ki új termékeket (élelmi- } \\
\text { szer, táplálékkiegészítő), amelyek nemrég } \\
\text { jelentek meg a piacon. (I like to try new pro- } \\
\text { ducts - food, supplement- which have been } \\
\text { released recently.) }\end{array}$ & 3,05 & 3 & 4 & 1,310 & $-0,103$ \\
\hline $\begin{array}{l}\text { Élelmiszervásárlásnál elönyben részesítem a } \\
\text { bioélelmiszereket. (I prefer organic products } \\
\text { during shopping.) }\end{array}$ & 2,97 & 3 & 4 & 1,221 & $-0,186$ \\
\hline $\begin{array}{l}\text { Előszeretettel fogyasztok sportitalokat. (I like } \\
\text { to consume sport drinks.) }\end{array}$ & 2,87 & 3 & 1 & 1,425 & 0,057 \\
\hline $\begin{array}{l}\text { Előszeretettel fogyasztok energiaszeleteket. ( } \\
\text { like to consume energy bars.) }\end{array}$ & 2,60 & 2 & 1 & 1,391 & 0,411 \\
\hline $\begin{array}{l}\text { Folyamatosan követem az aktuális innováci- } \\
\text { ókat, trendeket az élelmiszerpiacon és ennek } \\
\text { megfelelően alakítom ki étrendemet. (I keep } \\
\text { up with the latest trends on the food market } \\
\text { and I like to plan my diet based on these.) }\end{array}$ & 2,59 & 3 & 2 & 1,247 & 0,295 \\
\hline $\begin{array}{l}\text { Előszeretettel fogyasztok sport-tápszereket. } \\
\text { (I like to consume sport starters.) }\end{array}$ & 2,37 & 2 & 1 & 1,342 & 0,538 \\
\hline $\begin{array}{l}\text { A különböző étrendkiegészítők hozzájárulnak } \\
\text { a teljesítményem fokozásához. (The different } \\
\text { types of supplements contribute to increase } \\
\text { my performance.) }\end{array}$ & 2,32 & 2 & 1 & 1,307 & 0,574 \\
\hline
\end{tabular}

Forrás (Source): Saját szerkesztés a kérdőíves megkérdezés alapján, 2019 (Author’s own compilation according to questionnaire survey, 2019)

Megjegyzés (Notes): 1 - egyáltalán nem értek egyet, 5 - teljesen egyetértek (1 - I totally disagree, 5 - I totally agree) 


\section{KöVETKEZTETÉSEK -}

\section{CONCLUSIONS}

A tanulmány alapján elmondható, hogy a fiatal sportolók tisztában vannak az egészségtudatos táplálkozás fontosságával, azonban a mindennapjaik során valószínúleg a rutin (pl: iskolában megszokott rendszeres étkezés) és nem a célirányos egészségtudatosság irányítja őket, ám ez ebben a fogékony korban még külső segítség hatására pozitív irányban fejleszthető. Az pozitívum, hogy többségük tudja, hogy a felkészülési és versenyperiódusokban fontos, hogy odafigyeljenek a kiegyensúlyozott táplálkozásra, ám az további vizsgálatokat igényelne, hogy mit értenek ők ezalatt.

A megfelelő információkkal való ellátásuk azért is lenne fontos, hiszen az orvostudományi ajánlásokat alig ismerik, veszik figyelembe, így fontos lenne konzultációs lehetőséget (sportdietetikus, sportorvos), előadásokat és lehetőséget biztosítani számukra a jó gyakorlatok rutinba való beépülésére. Ezenkívül számukra is segítség lehetne, ha pontos ismeretekkel rendelkeznének az egyes élelmiszerek hatásával kapcsolatban, és biztosítva lenne a személyre szabott - legalább egyszeri - konzultáció a sportág és egyéni paramétereik mentén. Ebben akár állami szintü, de legalábbis regionális öszszefogás is segíthetne.

Bár az egészen fiatal versenysportolókat még nem mindig tekinti potenciális piacának a táplálékkiegészítő szektor, a fiatalkorban kialakuló rutinok okán hosszú távon jó befektetésként a rájuk való odafigyelés megtérülhet. Továbbá nem elhanyagolható, hogy a fiatal korosztály számára is segítséget jelenthetnek a megfelelő összetételű, jó minőségű termékek.

\section{6. ÖSSZEFOGLALÁS - SUMMARY}

Kutatásunk célja a fiatal, versenysportot űző egyének étkezési szokásainak megismerése volt, hiszen a szakirodalomból és a közéletből is tudhatjuk, hogy a megfelelően összeállított diéta komoly hatással lehet a sportteljesítményre.

Szekunder kutatásunk során a témában aktuális magyar és külföldi szakirodalmakat kutattuk fel és elemeztük. Primer felmérésünk során pedig kérdőíves megkérdezést alkalmaztunk, online és papír alapon való megkérdezés formájában egyaránt. Összesen 203 választ sikerült összegyüjteni, amiből 190 alany válasza került kiértékelésre, mivel ők alkották célcsoportunkat. Az eredmények feldolgozásához SPSS 22.0 statisztikai elemzőprogramot használtunk. Az eredmények elemzése után csupán azokat az adatokat tüntettük fel, ahol a Khí-négyzet próba alapján szignifikáns összefüggéseket találtunk $(\mathrm{p}<0,05)$. Ezután levontuk következtetéseinket és megfogalmaztuk javaslatainkat. Úgy gondoljuk hiteles információkat tudtunk feltárni a fiatal versenysportolók egészségtudatos étkezési szokásait illetően.

\section{KöSZÖNETNYILVÁNÍTÁS -}

\section{ACKNOWLEDGEMENT}

A publikáció elkészítését az EFOP-3.6.116- 2016-00022 számú projekt támogatta. A projekt az Európai Unió támogatásával, az Európai Szociális Alap társfinanszírozásával valósult meg.

\section{IRODALOMJEGYZÉK - REFERENCES}

Bagdy, E.: Vitalitásgenerátorok. LAM Lege Artis Medicinae, 2010. 20 (1) 6-7.

Boros, Sz.: Sporttáplálkozás. Krea-Fitt Kft., Budapest, 2008. 92-93.

Dudás, K.: $\mathrm{Az}$ egészségtudatos vásárlói magatartás jellemzői - szakirodalmi összefoglalás. Irodalomkutatás eredményei. Pécsi Tudományegyetem, Pécs, 2015.

Figler, M.: A Sporttáplálkozás alapjai. Pécsi Tudományegyetem Egészségtudományi Kar, Pécs, 2015.

Foltin, B. (2019): Wellness szolgáltatások igénybevétele a fiatal versenysportolók körében. In: Veres, Z. - Sasné Grósz, A. - Liska, F. (szerk.): Ismerjük a vevők? A vásárlás pszichológiája - Az Egyesület a Marketing Oktatásért és Kutatásért XXV. Országos Konferenciájának előadásai. Pannon Egyetem: Veszprém. 2019. 85-96. 
Harris, D. M. - Guten, S.: Health Protecting Behaviour: Anexploratory Study. Journal of Health and Social Behaviour. 1979. 20 (1) 17-29. DOI: https://doi. org/10.2307/2136475

Kasl, S. V. - Cobb, S.: Health Behavior, Illness Behavior and Sick Role Behavior. Archives of Environmental Health. 1966. 12 (2) 246-266. DOI: https://doi.org/10. 1080/00039896.1966.10664421

Kiss, V. Á.: A középiskolások életstílus klaszterei - különös tekintettel a rizikómagatartásra. Köztes-Európa. 2017. 9 (1-2) 97-104.

Kiss, V. Á. - Kovács, S. - Szakály, Z.: A fenntartható fejlődés értékei és az egészségtudatos életstílus elemzése középiskolás diákok körében. Táplálkozásmarketing. 2016. 3 (2) 4162. DOI: https://doi.org/10.20494/ $\mathrm{TM} / 3 / 2 / 4$

Nyakas, Cs.: Sporttáplálkozás. Egészségfejlesztés és Sporttudomány Tudásközpont Sporttudományi Intézet, Eszterházy Károly Főiskola. 2009. https:// sporttudomany.uni-eszterhazy.hu/public/ uploads/sporttaplalkozas-elmelet-esgyakorlat_572ao850e6c39.pdf (Letöltés dátuma: 2019.01.25.)

Maughan, R.: The Athlete's Diet: Nutritional Goals and Dietary Strategies. Nutrition Society. 2002. 61 (1) 87-96. DOI: https:// doi.org/10.1079/pns2001132
Mikulán, R.: A sportolók energiaigénye. Szegedi Tudományegyetem, Szeged, 2019. www.jgypk.hu/tamop13e/tananyag_ html/tananyag_sportorvos/i2_a_ sportolk_energiaignye.html (Letöltés dátuma: 2019.01.27.)

Silye, G.: Sporttáplálkozás a maximális teljesítményhez - Táplálkozási kézikönyv sportolóknak. ExSol-Group Kft., Budapest, 2017.

Szakály, Z.: Trendek és tendenciák a funkcionális élelmiszerek piacán: Mit vár el a hazai fogyasztó? Élelmiszer, Táplálkozás és Marketing. 2008. 5 (2-3) 3-11.

Szakály, Z.: Egészségmagatartás és funkcionális élelmiszerek: Hogyan vélekednek a hazai fogyasztók? Élelmiszer, Táplálkozás és Marketing. 2009. 6 (1-2) 9-18.

Tihanyi, A. - Várhegyi, M. - Klima, A.: Általános sporttáplálkozási szempontok egészségsportolók és szabadidő-sportolók számára. Új Diéta. 2015. 24 (2-3) 7-10.

Urbán, R.: Útban a magatartásszempontú egészségpszichológia felé: $\mathrm{Az}$ egészségmegtartás pszichológiai elemzése. Magyar Pszichológiai Szemle. 2001. 56 (4) 593-622. DOI: https://doi.org/10.1556/ MPSzle.56.2001.4.5

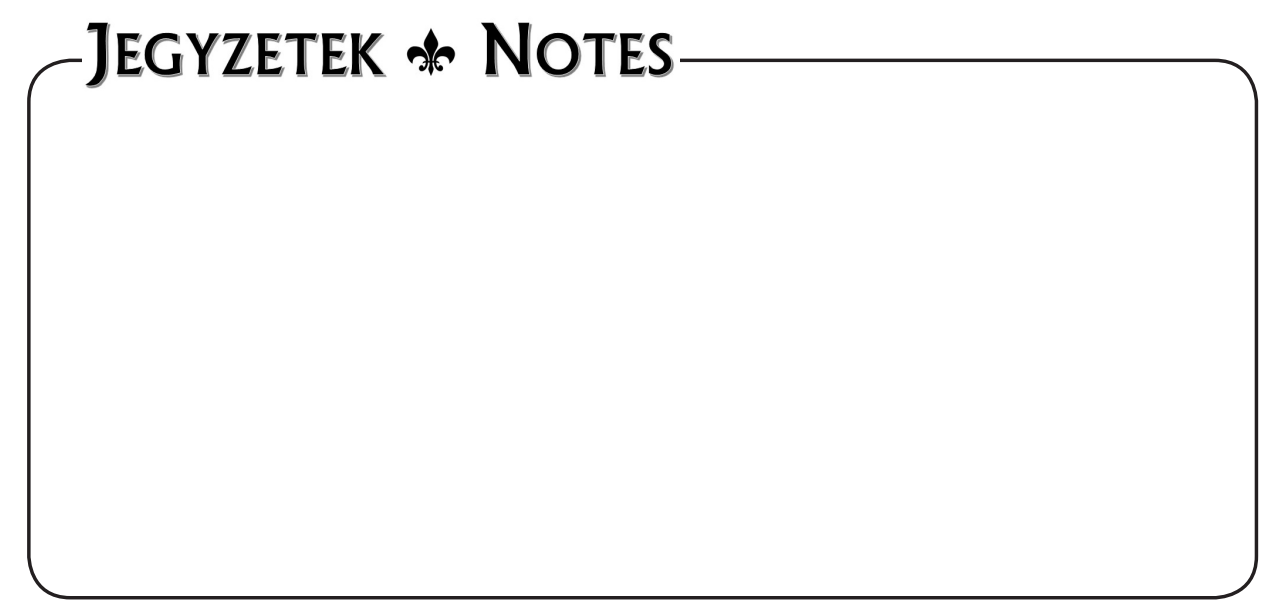

